Portland State University

PDXScholar

$5-24-2017$

\title{
Diversity and Inclusion in Pacific Northwest Theatre \& Strategies to Improve the Success of These Pursuits
}

Madelyn M. Odegaard

Portland State University

Follow this and additional works at: https://pdxscholar.library.pdx.edu/honorstheses

Let us know how access to this document benefits you.

\section{Recommended Citation}

Odegaard, Madelyn M., "Diversity and Inclusion in Pacific Northwest Theatre \& Strategies to Improve the Success of These Pursuits" (2017). University Honors Theses. Paper 399.

https://doi.org/10.15760/honors.395

This Thesis is brought to you for free and open access. It has been accepted for inclusion in University Honors Theses by an authorized administrator of PDXScholar. Please contact us if we can make this document more accessible: pdxscholar@pdx.edu. 


\author{
Diversity and Inclusion in Pacific Northwest Theatre \\ \& Strategies to Improve the Success of These Pursuits
}

by

Madelyn Odegaard

An undergraduate honors thesis submitted in partial fulfillment of the requirements for the degree of

Bachelor of Arts

in

University Honors

and

Communication Studies

Thesis Advisor

Karin Magaldi

Portland State University

2017 


\begin{abstract}
This paper seeks to explore the state of Pacific Northwest theatre and how successful theatre companies in this region are at promoting diversity and inclusion. This will first be accomplished by an extensive literature review and analysis. This will include sections discussing the current state of theatre in America and its importance, an introduction to the people, pieces and companies setting the example for diverse and inclusive theatre practices, the national theatre versus regional theatre debate, and successful integrative strategies used by companies and by specific individuals. After this is established, there will be a report on interviews that have been conducted with local PNW theatre companies. Finally, after looking to strategies used across the country and examining it in relation to PNW voices, I will propose suggestions as to how the PNW can grow with presenting and fostering theatre that is diverse and inclusive.
\end{abstract}

Keywords: Pacific Northwest Theatre, PNW, Diversity and Inclusion 


\section{Diversity and Inclusion in Pacific Northwest Theatre}

\& Strategies to Improve the Success of These Pursuits

Many of you may read the title of my thesis and scratch your heads. I understand not everyone has the same passion for theatre as I do. Theatre has played a significant part in my life for many years and having been an intern at a Portland theatre company for almost a year now, I see the importance of analyzing how successful Portland theatre is at presenting diverse and inclusive theatre. I often sit in on a performance of a show and am mesmerized, but I am often the youngest one in the audience. Not only that, but there are very few people of color. As someone who wants to work for a marketing or public relations department of a theatre company one day, I have become passionate about reaching those demographics who are often not sitting in these audiences. This brings me to the question I will answer of, "How successful is the Pacific Northwest (PNW) in presenting theatre that is diverse and aiming for inclusion? What could be accomplished to assist the current efforts?"

There are a few concepts that need to be clarified within this rabbit hole I have unearthed. I first must clarify what the PNW is, with regard to my research. Primarily, I will be discussing Portland-area theatre because it is from where I've received the most response. I have some information from a Seattle-area theatre company, which will also be included. Oftentimes, Montana, Idaho and Northern California are included under the PNW umbrella (de Place, 2010), but I wanted the research to be clear and manageable. Secondly, when I use the words "diverse" and "inclusive" I am referring to whether or not the theatre company, playwright, etc. is fostering art that welcomes all different kinds of people. Additionally, is it aimed at creating discussion and could it be used as a device for social change? Theatre in my research will include both plays 
and musicals. There are magnificent dance companies that have a similar aim as theatre companies, but that is not the focus, nor is it my expertise. Both are live and immediate forms of art, however, and provide unique experiences each night. A movie, TV show, or other similar mediums do not offer that. There is also the associated concept of accessibility that will be discussed, such as whether or not those that are Deaf or Blind have ways to enjoy the medium.

Fleshing out this thesis will first include an extensive literature review and analysis. This will include sections discussing the current state of theatre in America and its importance, an introduction to the people, pieces, and companies setting the example for diverse and inclusive theatre practices, the national theatre versus regional theatre debate, and successful integrative strategies used by companies and by specific individuals. After this is established, there will be a report on interviews that have been conducted with local PNW theatre companies. Here, I will answer the question I stated earlier. One of the reasons I was driven to write this piece is that I noticed a gap in the literature. It was necessary to go out and find local perspectives myself. Finally, after looking to strategies used across the country and examining it in relation to PNW voices, I will propose suggestions as to how the PNW can grow with presenting and fostering theatre that is diverse and inclusive. Hopefully, this can then result in more people visiting a theatre and seeing a performance.

\section{Literature Review \& Analysis}

To be able to progress to a discussion on PNW theatre, there first needs to be a foundation provided for what our nation as a whole is dealing with theatre-wise. Although there is a general lack of literature surrounding the PNW in this area of discussion, there is plenty of literature discussing the broader topic of diversity and inclusion in theatre companies nationally. 


\section{Current State of Theatre in America \& Its Importance}

When theatre is brought up in America, the majority of people likely think of Broadway, with the lit-up marquees and lines out the door. I'll often hear Les Miserables, The Phantom of the Opera, Wicked and the likes name-dropped when I begin to discuss my love for theatre. Although these are undoubtedly prominent and popular shows, that is not all there is to theatre. This does not discount the mentioned shows' widespread appeal and importance. These pieces bring the average person to the theatre who may not be drawn to theatre otherwise.

Hamilton is the latest craze on Broadway and it is often praised for its ethnically diverse, or even color-blind, cast portraying historical figureheads that were of European descent. Demby (2016), a blogger who often discusses race and politics, describes his experience sitting in the audience at performance of Hamilton. Demby was impressed by the casting choices, but he was the only African-American man sitting in the theatre surrounded by hundreds of white men and women. He suggests that this could be due to a history of racism and segregated seating at theatre. Many demographics may not feel welcome for historical reasons. Not only that, but the tickets can run upwards of over \$200, which is unaffordable for many. McMaster (2016), a Ph.D. performance studies student at NYU, also critiques Hamilton for similar reasons, one being that putting such a diverse ensemble within a white historical context takes away from the extreme violence and oppression that people of color had to face during that time period.

Aside from the issue of race, McMaster also sees an issue with Hamilton's feminist messages. Although there are strong women in the cast, the men still have a tremendous upper-hand. The immigrant experience is also represented, however it seems to only highlight when an immigrant becomes powerful and successful. Immigrant experiences are not typically 
this extravagant. The story is not representative of a traditional immigrant's journey. These critiques are not discussed often in day to day talk, as there is such sensationalism that surrounds the production. It's a challenge to speak up and be reflexive about what everyone is raving about.

Considering the influence of Broadway on the theatre community, looking to the demographics of people attending Broadway shows may be quite telling of the condition of the theatre community as a whole. Looking to 2015 demographic information from The Broadway League, $68 \%$ of theatregoers were women, the average age was 44 -years-old, $80 \%$ of people who bought tickets were caucasian, and for theatregoers over the age of $25,78 \%$ were college graduates and $40 \%$ earned a graduate degree. Looking to these statistics, it is clear that there are certain demographics that attend Broadway shows more than others. There is an apparent lack of diversity within theatregoers on a national scale. There are differences within PNW theatre, as will be highlighted later in this paper. Unfortunately, PNW theatre finds itself with an even less diverse audience base.

The glitz of Broadway can often be blinding, but it is not the only theatre that holds significance. Theatre extends into every region in the country. There are some nationwide issues that theatre companies are having to face. One of these issues is whitewashing of characters within a production. In Clement's (2017a) article, she describes the 2016 scandal when Lincolnshire's Marriott Theatre cast Evita, the story of the influential First Lady of Argentina, with non-Argentinian individuals. The company has since attempted to correct their actions, but this is not an uncommon practice within the theatre community. Through this scandal, there has been activism created to teach actors to be aware of the roles for which they are auditioning. This project began with actress Lauren Villegas and she will be discussed more in the next section of 
this paper. Many theatre companies do embark on quite extensive casting searches to find actors that fit specific role descriptions, but this is obviously an extra expense of both money and time that could discourage theatre companies.

Shaw (2016) attempts to exploit the inequity of fairness within the people creating theatre. Specifically, playwrights are undervalued and underpaid, even if their work is headlined on Broadway. They are usually unprotected, compared to actors, who are protected under the Actors' Equity Association. Additionally, with all of these hopeful artists creating work, it would be challenging for them all to be recognized by critics, who often provide a perceived credibility to the public. With these talented playwrights come more trained actors, as many are going to school to get a Master of Fine Arts degree or other specialized theatre degrees. Before, most actors were known as having a distinctly "raw" talent. Everyone has heard of the young actor moving to Broadway and making it big. That is becoming more rare. Many, such as Shaw, contribute these factors into the argument that Broadway, and theatre in general, is becoming more elitist.

A much larger barrier for success is overviewed in Grunfeld's (2015) work. Being actively involved in the New York theatre community, he supports funding for the arts. Many conservatives do not feel the same way. Now more than ever, the arts are being threatened. It sometimes feels bleak to read about these battles, but there is much to be praised as well. Unfortunately, as Eyring (2016) details, attendance at theatre companies as a whole has been going down, but there has actually been a $14 \%$ increase in children attending theatrical performances. As many theatre companies have goals of producing challenging, diverse theatre 
geared more toward adults, some theatre companies are shifting some focus to underrepresented demographics. This shift is highlighted in a later portion of this paper.

The importance of making theatre welcoming and accessible to all ages and demographics is evident because theatre companies are often touted as "safe spaces." Oftentimes, they are places that people can turn to when they are in need of healing. Tran (2016) overviews the theatre community's response to the 2016 Pulse tragedy in Orlando and how safe spaces are necessary, especially in times of tragedy. Theatre also has the ability to respond to tragedy much faster than a book, a film, or a television show could. It is immediate and does not always need that polished editing, especially when it is needed quickly as a way for audiences to heal. By mid-August, only two months after the tragedy, dozens of theatre companies around the nation dedicated nights in remembrance of the lives lost. There were theatre companies represented on both the East and West Coast and even internationally.

Bhattacharya and Gupta (2013) are both communication scholars, but they also understand the value of theatre. For those not involved in the theatre community, there is the stigma that theatre is merely a form of entertainment. Bhattacharya and Gupta outline how theatre can also inform, instruct, persuade, educate, and develop. The stage mirrors life and the actors mirror the audience. Therefore, theatre has and will be a vital form of communication for the world.

Perez and Corey (2015), both associated with the School of Letters and Sciences at Arizona State University, contribute to the same conversation as Bhattacharya and Gupta. They posit that theatre is not only a vital form of communication, but it is very intimate and personal. At the core of this argument are access and accessibility. The performers must be able to access 
the moment and the experiences within the piece. The audiences must then be able to understand the performance, which is the accessibility aspect. There must be both in order for the transaction to be successful. The transaction will not always transpire the same way, however, because everyone's experiences differ. There also needs to be effort put forth by both the performers and the audiences. It is an undoubtedly complex, but important, way to look at how theatre can be successful.

Looking to the current state of theatre in America, first, and then to its importance, secondly, it is made clear that theatre must be protected and supported. Being that it is a vital form of communication, it is unlikely that it will ever be without its flaws. However, the state of theatre in America is ever-changing and its challenges can and should be fought through. Of course, each region faces its own challenges and has its own successes, as we will see in future sections.

\section{People, Pieces, and Companies Setting the Example}

It would be a mistake to discuss diverse and inclusive theatre without featuring people, specific pieces, and theatre companies that are forwarding the success of these goals. Although discussing the issue at large is important, breaking that down to specific case studies is just as important. One of the people working to create a more authentic theatre community is Lauren Villegas, who is discussed in Clement's (2017a) article. Villegas created Project Am I Right, in response to the production that cast non-Argentinean actors in Evita. Working with the Actors' Equity Association, which is the labor union representing American actors and Actors' Equity Foundation, which supports these pursuits, she is teaching actors to be considerate allies when choosing to audition for certain roles. This essentially means that if a character is a certain race, 
someone who is not that race should not audition. Villegas' pursuits have proven successful. Lincolnshire's Marriott Theatre, who pinned the controversy, have since been working on correcting their mistakes.

Rose's (2011) piece headlines Anna Deavere Smith, who is known for her “documentary theatre" or performance ethnography. She transforms into many different characters during her performances, many of which may be surprising to her audiences. For example, she once portrayed Paulette Jenkins, who is a Korean shopkeeper and a bull rider, despite the fact that Smith is a black woman (TED, 2007). She encourages others to remember the entire process behind creating a piece of theatre. Theatre is so much more than a static performance. Her pieces are often extremely experimental and provocative, and she often is discouraged by negative reviews, but those who understand her messages make the work rewarding. Her work is Perez and Corey's argument in action. As discussed in the last section, the audience and the performers have to work to create shared meaning in a transaction. Although not everyone will understand her messages, she creates art that is as accessible as possible for her audiences.

Luis Alfaro, who recently spoke at the 31st Annual Literary Managers and Dramaturgs of the Americas Conference (2016), has similar success. Alfaro is a playwright who works with many national theatre companies and often is involved with long-term residencies to transform theatre companies. Activist theatre is at the forefront and he wants to "bring light to what is dark." He posits that to be successful, companies must create theatre that is relevant to the community, but also the staff. There is also a need for clear communication with everyone contributing to a production. More of Alfaro's strategies will be discussed in a forthcoming section, but he deserves credit up front for the work he creates and his progressive approaches. 
Activist theatre is a focus within the Fringe Benefits Theatre for Social Justice Institute Program. Bowles and Nadon (2013) published a book comprising short essays of individuals that have been involved in productions within the program. Productions are found in different cities in the United States and even internationally. Their goal is to connect theatre to a city. Like Alfaro, the goal of these productions is to work with a community from the ground up to create a piece that is relevant to them. They understand that theatre is a safe space, which is an interesting balance when there are stories being shared. Oftentimes local stories end up in the finished product. Even though this is a challenge for many people facilitating the program, the work is authentic and true. There are many productions highlighted in this book, some more successful than others, but it is evident the global impact Fringe Benefits has had on communities.

The Culture Clash performance troupe travels to various areas where they see need, similar to Fringe Benefits, but they tend to target Mexican-Americans. In their 2013 book, it is shown that they address the different Chicano-Latino subcultures within different regions of the United States. The work in this book highlights San Diego county and Tijuana, New York City, San Francisco, and Washington, D.C. In each city, Culture Clash's goal was to unearth a deeper understanding of racism and to create self-reflexive audiences. They understand that they cannot sum up an entire culture, but challenging the norms is what is critical. The issues will always be evolving, so challenging the norms will also be important.

Other theatre companies might not have this sort of intense activist theatre as a focus, but they still rose to the occasion when they saw a need. For example, the Marin Shakespeare Company in San Rafael, California is one of many theatre companies who are piloting theatre programs for prison inmates. Zoukis (2017) outlines the Shakespeare for Social Justice Program 
that reaches many inmates in Northern California prisons. The inmates not only perform classical texts, but they write their own pieces as well. Marin has created an additional program for when the inmates are released so that they still have a way to learn and grow through theatre within a non-judgmental environment. Theatre equips inmates with skills, such as cooperation and teamwork, that can guide them to a better quality of life and a better way to deal with challenging situations they may encounter. Marin, and many other organizations, saw an opportunity to reach a group of people who do not have access to theatre and they went directly to them.

Missing Bolt Productions is another theatre company that reacts to a need and meets that need through theatre. We see in Tran's article, mentioned earlier, that there was a huge reaction from the theatre community when the Pulse tragedy in Orlando occurred. That reaction began from co-artistic directors of Missing Bolt, Blair Baker and Zac Kline. They then contacted playwright Caridad Svich, founder of NoPassport, who is known for her expansive theatrical vision. Before this, she had done a similar nationwide event on climate change. Together, they invited playwrights to write short pieces that were in response to the tragedy. The series of over 60 events occurred nationwide between September 2016-January 2017 and were all under the name After Orlando. A movement like this shows a sense of solidarity and continues the discussion.

What has been discussed in this section so far is fairly current, but theatre has been evolving for thousands of years. A turning point in contemporary theatre occurred when playwright Frank Wedekind wrote the play Spring Awakening. Journey (2015) writes about Wedekind's groundbreaking work. Theatre is like every other medium in that there are trends 
that come and go. Obviously, Hamilton would not have been created hundreds of years ago because that was not a style of theatre or even music that was available. However, many would be surprised to hear of the content that Wedekind created in the late-1800s. Wedekind addressed issues such as rape, homosexuality, and teenage pregnancy. Journey argues that Wedekind began the twentieth-century trend of focusing on youth culture within drama and literature. Wedekind addressed topics that were considered taboo and he challenged the rules that had been constructed for drama and literature. He even served time in prison for some of his content.

Wedekind was unafraid to admit much about the culture before most could even admit it aloud, similarly to Anton Chekhov. Wedekind's translator admits that if he was born a hundred years later, he probably would have been a rockstar. Spring Awakening was trying to reach a new audience that was not addressed before Wedekind. Although unfavorable to many, Wedekind exposed the anxieties of the time, that made other authors and playwrights feel it acceptable to also address similar topics. The bigger picture extending past Spring Awakening is that Wedekind was not aiming for a mass appeal. Instead, he was creating a piece that would resonate with people that theatre was not addressing. His work was even adapted into a 2006 Tony Award-winning musical. Although trends change, people face similar issues throughout the years. At times, it takes one strong voice to be brave enough to discuss the difficult topics.

Obviously, this brief passing through some of the people, pieces, and companies that have contributed to diverse and inclusive theatre is not an exhaustive one. An entire thesis could be devoted to this area. The goal of this section was to give some context as to what small voices can do, to contribute to the greater theatre community. Later, we will hear from Pacific 
Northwest voices and what theatre companies locally are doing, or are not doing, to impact the theatre community as a whole.

\section{The Great National Theatre Versus Regional Theatre Debate}

Thus far, it would seem that a regional theatre focus is and should be favored by all. This is not the opinion of everyone, however. Many find the idea of a United States national theatre a way to set the example and could be a unifier for other smaller theatre companies. There is the example of the National Theatre in London being a success. Grunfeld, who was mentioned previously, writes on the history of a national theatre in the United States during Franklin Delano Roosevelt's time serving as President of our country. The Federal Theatre Project started out successfully, at one point employing over 10,000 artists from 40 states. Congress eventually cut spending and that was the end of that venture. Grunfeld sees the value in funding a similar project, but it is problematic. There is the issue of where the centralized location would be and, of course, we aren't in a political climate that would necessarily agree to such funding without immense debate. Grunfeld eventually does say that regional theatre companies are going to have to suffice, but there does seem to lack of an overall national vision.

The majority of people would argue that the regional theatre movement makes more sense because it features more local issues, as has been a common theme thus far in this paper. O'Quinn (2015), the co-founder of the American Theatre magazine, writes an account of the regional theatre movement. It began in the 1960s, where the Ford Foundation began funding grants to support "resident theatres" in the US. Before this resulted growth, actors did not see a successful life of acting outside of New York. Unless an individual lived near the few other established theatre companies, quality theatre was very inaccessible. The establishment of 
Minneapolis' Guthrie Theatre in 1963 was the event that set the example for regional theatre in America. People associated with Broadway and other reputable areas of theatre legitimized the institution and informally gave permission to make great theatre across the country. As of 2005, there were over 1,200 across the country and that number continues to grow. O'Quinn argues that regional theatre companies truly create a national theatre collective without America having a designated national theatre.

Aucoin (2012), a Boston area theatre critic speaks on reaching out to niche markets and tailoring theatre to them. A national theatre is a nice idea, but the beauty of theatre, in Aucoin's eyes, is that it can reach smaller, more specific audiences. Film and television do not have that same ability due to mass distribution. Alfaro, at the 2017 Literary Managers and Dramaturgs of the Americas Conference, discusses this as well, in that he understands that theatre will only be successful if a piece resonates with its audiences. This same kind of specific care would be challenging on a national level, however there are of course national issues that could be broadly addressed. The consideration here is that these issues manifest in different ways within each community or region.

We see this targeted approach in both Fringe Benefits and Culture Clash. Fringe Benefits went into numerous communities to create pieces of work that the region needed. The goal with these pieces was for them to be utilized as a device for social change. Culture Clash has similar goals, but they specifically look to racist manifestations within various regions. These recent examples are not permanent theatre companies that house in one city, but they are examples of how each region is unique and can benefit from varying strategies. Some companies might find it 
important to address issues on a needed basis, as Fringe Benefits does. Other companies may address issues through a certain lens, as Culture Clash does.

There is value in the variation of regional theatres, but there is still the common thread of working toward change. In Tran's piece on the Orlando tragedy, we see a huge nationally connected link. This is, arguably, what a national theatre minded regional theatre collective looks like. It is accessible to many across the country, it encourages unity, and it still is tailored to a specific community. Garrison (2017) discusses the Ghostlight Project, which was a theatre-focused event that was even more widespread than After Orlando. It was an event held at theatre companies across the country on January 19, 2017, but it was not performance based. Inspired by the current political climate, the aim was to remind the theatre community to be a "light" during dark times and to reiterate that theatres are a place for everyone of every background to congregate.

With the success of what theatre communities can do regionally, a national theatre seems to be a less popular concept. As we see with the example of Lincolnshire's Marriott Theatre, regional theatre companies are not always going to be a place that encourages diversity and inclusion. There are struggles nationally and locally. With hashing this "national v. regional" debate, however, it at least seems that addressing struggles on a local level seems to be a much more manageable place to begin, rather than becoming bogged down by all that needs to happen on a wider scale.

\section{Strategies for Presenting Diverse \& Inclusive Theatre}

As it seems like a regional focus is an appropriate place to begin in the pursuit for diverse and inclusive theatre, we are now brought back to the people and theatre companies who have 
established effective strategies that can be of use to others with similar goals in mind.

Bhattacharya and Gupta make an important statement, brought up earlier, that theatre is not merely a form of entertainment. There is often the misconception that this is the case, but it can also inform, instruct, persuade, educate and develop. Theatre companies must keep this in mind when presenting theatre. Of course, some theatre companies may only want to entertain, but there must be an awareness that there is the ability to do much more than that.

Perez and Corey, with their focus on access and accessibility, would encourage theatre companies to be aware that they are not simply presenting a piece of work, but rather they also must be successful at reaching audience members on an intimate level. In the hectic theatre business, it is often forgotten that the goal is not only to "get the show up and running." If the audience doesn't internalize the intended meaning and takeaway, then the transaction has failed. Care must be taken throughout the entire process of creating a piece of theatre so that this is avoided. Anna Deavere Smith also reminds that individuals in an audience are not a homogenous group. There must be the goal of a successful audience take away, but reasonable expectations are necessary and can prevent becoming overwhelmed and defeated. Audience members are not going to have the same interpretations of a piece.

Bowles and Nadon, with their Fringe Benefits approach, offer a key strategy when considering the audiences. There is a fine line that needs to be taken when presenting particularly activist theatre. There is the possibility that this theatre can come across as "preaching to the choir." The intended goal is to be involved with consciousness-raising of an issue or issues. This is where keeping a local focus is a strategy to consider, as the topics are honed in and meant for the community in which it is being presented. Pre and post-show discussions are named as a way 
to work through the content of a show and a way to promote consciousness-raising. Alfaro's work is exemplary of consciousness-raising without being preachy. He molds work to be relevant to the community he is in, but he also assures that it is relevant to the staff involved and the cast. Together, there is a level consciousness-raising on both ends that makes the transaction successful.

Alfaro also has two other unique strategies that set his work apart. He has taken classical Greek texts and made them relevant in modern times. This is reminiscent of how Wedekind's transformed 2006 Spring Awakening still discussed topics that people 100 years earlier were facing. Alfaro's transformations connect the past to the present. He has also been known to have two different casts for different nights of a production, in hopes of being relatable to multiple demographics. What happens is that the audiences do tend to match the casts performing. In one case, he ended up blending the casts together, after the initial experiment was successful, and the audiences did become more diverse. Theatre companies who want to present diverse and inclusive theatre have the power to showcase the work of playwrights like Alfaro. Strategies that go into creating a piece of art are just as important a choice as what a theatre company chooses to present.

Theatre companies casting race-specific roles must also keep in mind the identities of who they choose to cast. Clement's (2017a) article warns of the backlash that can occur when an inappropriate casting decision is made. That should not be the only consideration taken into account, however. Theatre is a representation of life, and authenticity within a cast will better reflect real-world situations. There are also oftentimes fewer roles for people of certain races, so this is instrumental in creating a fair environment for actors. Aucoin agrees with Clement, in that 
theatre companies have the power to make more diverse casting decisions. Project Am I Right makes actors aware as well because if they don't audition for these roles in the first place, then there will not be the chance they will be cast. This is a two-way street, but both actors and theatre companies can take precautions to preserve the authenticity of theatre.

Another consideration must be made to children. Eyring discusses how many theatre companies are beginning to incorporate children into their mission statements and goals as a company. There are still many theatre companies who have not made this adjustment. As attendance by children at theatrical performances has risen, there is some clear evidence that including them is an effective strategy. Oftentimes there is this divide between adult and children's theatre, but just as Alfaro has experimented with obtaining a more diverse audience, there is the promise that this divide can become less black and white. This strategy extends much farther than filling empty seats, however. These children are going to be the adults of the future. It is critical to make them lifelong theatregoers and that will be possible if an effort is made to include them in the theatre community.

Aucoin suggests reaching out to young people through social media, which is already a strategy that many theatre companies use. It has the potential to tightly target this demographic. When it is so easy to sit at home and watch Netflix, there needs to be enticing marketing strategies to bring them to a theatre. Aucoin also suggests that staging new plays is a way to not only bring in unique audiences, but it encourages new playwrights to continue writing. Companies can support each other and prevent unnecessary expenses by sharing resources. Many theatre companies are surviving season to season. If theatre companies support each other, then they all are working for the cause of creating art for the community. Of course, this support 
is not only a resource concern. After Orlando and the Ghostlight Project showed that emotional solidarity is important as well. Sure, theatre is a business, but there is the larger goal of being a device for social change that is taken on by everyone collectively.

There is much to be done for those who work within the theatre community. As Shaw identifies, there is a shift to theatre professions being a trained art. This often means that those who are self-taught are at a disadvantage. Providing these artists with resources to succeed is critical to preserving these talents. There are also many professions in the theatre community that are not protected by a union, meaning they work many hours to get their work complete with no extra compensation. A playwright, for example, does not have the same protections as an actor. Advocating for these behind-the-scenes, but vital, roles is a strategy that must continue to be a focus.

One thing that many pieces of literature fail to mention is the topic of accessibility. No matter how well a theatre company reaches out to the community, sometimes there are still barriers that prevent people from seeing theatre. There are monetary issues preventing people from seeing theatre. Even though many theatre companies have initiatives to make their performances affordable, it still is not possible for many in the community. There is also the issue of location, on which there is a definite lack of literature. In the upcoming sections, resources for the Deaf and Blind will be addressed in a local context. Clement (2017b) showcased the military veterans who found their way to theatre. There are times when extra effort must be made in order to be considered inclusive and available to everyone.

Zoukis provides the example of when theatre companies must physically go to members of the community in order for them to experience theatre. For example, prison inmates cannot go 
out and seek theatre, but that does not mean that they cannot learn from and love theatre. That is why theatre companies that go out and provide prison inmates with programs are so important. It provides them with strategies that act as a sort of therapy. Many accounts of these programs show that these inmates are healed by theatre. Shaw is true in stating that theatre arts funding is lacking and could become even more damaged over the next few years, which is why theatre companies have to fight now more than ever to keep these cultural experiences intact for everyone.

\section{Pinpointing the Pacific Northwest}

As the focus shifts to the PNW, looking to specific demographic information can help us predict the likelihood that certain people might visit a theatre. Looking particularly to race, $85 \%$ of Oregonians are of European descent and 80.2\% of Washingtonians are of European descent. Idaho, often included under the PNW umbrella, is a surprising 92.3\% European descent (de Place, 2010)! The PNW is not the most ethnically diverse region of the country, which could indicate a lack of diversity. I have been gathering demographic information from Portland's Artists Repertory Theatre audiences this $2016 / 2017$ season, mostly in part for their purposes. It is a stark contrast from The Broadway League's statistics mentioned earlier. As of May 30, 2017, 2,717 responses have been gathered, from a total of 9 productions. $92.5 \%$ of respondents were of white or European descent, versus the $80 \%$ that The Broadway League found. $60.1 \%$ of respondents were female, versus the $68 \%$ that The Broadway League found. The most common age bracket at Artists Rep was 66-75 (33.9\% of respondents), compared to the average Broadway theatregoer being 44-years-old. 
There are also additional musings that cannot be compared to any other data made readily available by The Broadway League. $38.6 \%$ of Artists Rep attendees were heterosexual, although $47.2 \%$ of respondents declined a response. The most common household income bracket was $\$ 90-199 \mathrm{k}(36.8 \%)$ and the most common size of household bracket was two $(59.1 \%)$. This is a lot of data leading to the conclusion that common theatregoers in Portland are straight, heterosexual white couples, making over $\$ 90,000$ per year. It is interesting to note that there are a lot more men visiting Portland theatre, compared to the Broadway standard. Most troubling is the lack of ethnically diverse audiences. Even with Oregon being $85 \%$ white, there is a $7.5 \%$ difference between the state and who is visiting the theatre, at least in this theatre company's case. Of course, it should be noted that this could only be the case in Oregon, as I do not have leads in obtaining similar Washington demographics.

Having lived in the Pacific Northwest for most of my life, there is a discouraging amount of information on the complexity of diverse and inclusive theatre within a local context. Through the research done, one of the only mentions of PNW theatre was with the Bowles and Nadon book. They describe one PNW town as being the most divided they have ever seen and it was challenging for the group to come together to create theatre. Additionally, Garrison makes the statement that Portland is often seen as the "Whitest City in America." She makes the argument that Portland specifically has been known for its quirky stereotypes, but these stereotypes are predominantly associated with white people. There are plenty of important representations of strong African American Portlanders, particularly in art. More attention needs to be paid to them, as they are often overlooked amidst the "hipster" stereotype. These two pieces of literature are 
helpful in generating an understanding of the climate of Portland theatre, but there is not enough evidence to make definitive assumptions.

Considering this preceding information, I knew it was necessary to reach out to local theatre companies in Oregon and Washington to get their perspectives on the topic. I reached out to twenty companies and received data from six companies. I also connected with two other people within the theatre community who have many things to say about the state of PNW theatre. Another six theatre companies expressed their support, but unfortunately have not reported back with any official comments. The next portion of this section will summarize what these fantastic individuals, who took the time to help me, had to say. Please refer to appendices A and B for questions that were provided to guide the respondents.

\section{Broadway Rose Theatre Company: Tigard, OR}

Broadway Rose Theatre Company's Sharon Maroney, the Producing Artistic Director, responded to my request to have someone comment on behalf of the company (S. Maroney, personal communication, March 7, 2017). When I received a response, it was not what I had expected. Maroney expressed her lack of time to respond to my request, but she did make the statement saying that they "do not have a lot of diverse musical theater performers auditioning

for our theater." This was an interesting response, as it was one that indicated to me that diversity and inclusion may not be at the forefront of every theatre company, despite what I want to believe. It has me curious, however, if perhaps they need to take initiative and seek out a variety of people to audition for their shows. There is no way to know for certain, as the statement is brief, but this was an important reminder that not every theatre company has the aim of maintaining an activist edge. 


\section{Harlequin Productions: Olympia, WA}

Linda Whitney, the Artistic Director of the 26-year-old Harlequin Productions, provided me with the only opinion from a Washington theatre company, despite my best efforts to obtain other responses (L. Whitney, personal communication, February 28, 2017). Whitney has visited many local theatre companies throughout the past twenty years and she has noticed a trend towards inclusion and involvement. That being said, she understands that there is that core of seniors who have had "discretionary income and have had a rich life in travel and intellectual activity." Their average theatregoer is 55 . She mentions that young people do come to enjoy theatre, but it is often because they themselves are participating in it. Once they grow into adulthood, priorities often change and funds are used elsewhere. Many efforts are made to reach young people, as they are natural actors and storytellers. There are discounts in order for them to be able to afford productions that are suitable for them. They are also considering a program where grandparents receive a discount when they bring their grandchildren — an innovative idea I have never heard of before.

Whitney identifies an issue that is faced by many theatre companies - the issue of other technological distractions. She believes that social media meets similar needs of engagement, in the way that theatre has been used for thousands of years. It is competition. An obstacle for Washington state, in particular, is that funding for the arts is particularly low. According to Whitney, it's four states from the bottom in arts funding and has been that way for quite some time. Even though this is a challenge, they own their 212 seat house, have a full-time staff, and contract close to 200 people to be involved with their productions annually. They drive upwards of a million dollars in revenue, with the hard work of the staff. Although a business, and 
realizing that Thurston County is not the most racially diverse county in the state, they focus on being a place where issues of race and diversity can be safely explored. They also hold specific events that celebrate women and the LGBTQ communities. A final unique strategy they use to bring diverse crowds to the theatre is their community partnership program. A local non-profit has the opportunity to have a block of tickets for the final dress rehearsal of a straight play, for an affordable cost, and they can resell the tickets as a fundraiser or to their stakeholders as a benefit. Whitney's eagerness, and may I say fast response, to help with my thesis relays that Harlequin Productions is, and will continue to be, focused on community building.

\section{Imago Theatre: Portland, OR}

Jerry Mouawad, Artistic Co-Director of Imago Theatre, says it is a bit of a challenge to see other theatre in the region because of how busy he is creating theatre (J. Mouawad, personal communication, March 27, 2017). He notices a trend toward diversity on a larger scale, but understandably so, he doesn't care to make any assumptions when he is usually focused on his own work. Funding for the arts in Oregon, much like in Washington, have always been low and is becoming lower. Even in times of strife, however, the arts rise up and provide nourishment to people and their souls. Imago contributes to this by seeking out content that stretches usual form. Mouawad mentions their success in casting people of color, as well as recently having cast a Deaf actor for a lead character.

An important insight about Imago is that Mouawad doesn't see the "traditional" older demographic that most theatre companies see. They have two key strategies to draw in diverse audiences. Their first strategy is to create innovative, highly visual work for family audiences. Their second strategy involves targeting adults by being adventurous with the content produced. 
This indicates that perhaps audiences crave experimental work. Additionally, the observation that children value highly visual theatre could be a way for many theatre companies to make young people captivated by theatre.

\section{Oregon Children's Theatre: Portland, OR}

Coming from a company with a unique demographic is Marcella Crowson, Associate Artistic Director of Oregon Children's Theatre (M. Crowson, personal communication, April 7, 2017). Crowson recognizes that many theatre companies are very successful in presenting diverse and inclusive theatre. This is not representative of the theatre community in the PNW as a whole, however. The work within PNW theatre companies does not come close to being as authentic as it should be in 2017 . There is work to improve the state of PNW, but there still is a lot of catching up to do. She identifies that there is a much larger issue to overcome than diversity and inclusion. The larger task is to transform organizations by not only casting people of color and people with disabilities, but by giving them leadership positions within these organizations. Only when this happens will it become integrative over being understood as “special projects." She recognizes that most theatre companies do have good intentions. Crowson understands that theatre companies, including OCT, must start somewhere.

OCT has begun to make bigger strides in diversity and inclusion over the past decade. They've begun to make more intentional hiring decisions both in the office and on the stage. A staff workgroup has been formed to keep these goals in mind. They are a part of the Arts Leaders for Inclusion coalition. This fall, they will begin outreach to more rural, high Spanish-speaking populations to be able to expose them to theatre. Obviously, their main focus is their respect for young people. She makes a moving statement that there is power in a child seeing other children 
on stage. Many children grow up with the influence of OCT and thus, a "home" is created. A special partnership with Kaiser Permanente, that has been intact for $11+$ years, provides free theatre and programing to an average of 30,000 young people each year. OCT goes specifically to the children and works with them, rather than waiting around for them to visit the theatre. The Educational Theatre Program's mission is “Through theatre, we inspire people to make healthy choices and build strong communities.” They also extend to senior care facilities, to bring together high school students and the folks living there. Obviously, not every theatre company is going to have this specific children's theatre mindset, but a lot can be taken away from OCT's strategies.

\section{Portland Center Stage: Portland, OR}

Kelsey Tyler, the Education \& Community Programs Director at Portland Center Stage, feels similarly to Crowson (K. Tyler, personal communication, April 15, 2017). He believes that most theatre companies do strive for diversity and inclusion, some more than others certainly, but actually achieving this at a high level is much more challenging. He is very well aware that our city is predominantly white and that it is much more challenging to reach diverse audiences and to cast diverse artists compared to other cities. Close to five years ago, PCS hired an expert to help them with diversity and inclusion initiatives. They now make decisions through an "equity lens" and make steps to diversify in all areas, including staff, audiences, and choosing to produce certain plays. Like many theatre companies, they offer discounted tickets for those who may not be able to afford them at full price.

Their demographics may slight toward the traditional one I often refer to, but around 17\% of their audiences are 30 and under. This fares better than the $14.8 \%$ who are 35 and under at 
Artists Repertory Theatre. Aside from the pieces they present, they are focused on being a resource and a hub for the community. Not even taking into account their pre and post-show discussions, they offered close to 250 community programs last year. Their programs range from offering free tickets to individuals transitioning from homelessness to several programs aimed at children and young adults. Two of the programs they offer that offer something that I have not come across in other literature are Visions \& Voices and their teen council. Visions \& Voices is a playwriting program for high school students in the Portland area. They are able to present their work at the end of the year. PCS' teen council is a way for young people to increase their involvement in the theatre community that extends past taking a class and performing. Being the potentially the most recognizable theatre company in Portland, it's comforting to know that they are setting an appropriate example for others.

\section{Profile Theatre: Portland, OR}

Lauren Hanover, the former Interim Artistic Director, talked to me about Profile Theatre's 20th season (L. Hanover, personal communication, January 20, 2017). They have implemented a unique approach to their seasons for many years that was established by their original Artistic Director, Jane Unger. Their seasons revolve around one single playwright's body of work. They did this because they saw a hunger from their audiences to see the process of a playwright, not just the end result. When Adriana Baer took over as the Artistic Director, this mission was still intact, but it was taken even further. Now they focus their season on up-and-coming playwrights, rather than those who are already established. The first season that

had this focus honed in on Sarah Ruhl. It allows playwrights to be able to master their craft and it is also an honor for these playwrights to be asked to headline an entire season. They strive to 
focus on playwrights that are women and people of color, as the industry privileges certain people, primarily white men.

Another important side note is that they have very extensive ASL features. Many theatre companies in Portland offer ASL interpreted shows, but Profile has a core of volunteers that assist when these shows occur. There is not only an interpreter for the show, but there is someone at the door, at the concession stand, etc. They also offer to interpret their pre and/or post-show discussions, which Profile offers at every performance. On their YouTube channel, there are interpreted descriptions of each of their shows this season, which is welcoming to the Deaf community. Many do not know that ASL has different sentence structuring than English, which makes reading English more challenging than it needs to be for people who rely on ASL. Deeply discounted ASL season subscriptions are offered as well.

All of this considered, Hanover expresses that budget is something that cannot be ignored and is a contributing factor for who they choose to partner with. Some playwrights are outstanding, but a larger cast lends itself to a higher budget. There is a balance between content and cost. Above all else, however, Hanover reminds that theatre helps us have empathy, which is more important than ever. People should strive to see theatre about people unlike themselves.

\section{Two Rivers Theatre Program: Umatilla, OR}

Victoria Spencer is a current volunteer and co-facilitator for the Two Rivers Correctional Institution's theatre program, which men can voluntarily join (V. Spencer, personal communication, November 15, 2016). Spencer has a passion for applied theatre, which is basically used as a tool to address social change on a grassroots level. Like the Marin Shakespeare Company's Shakespeare for Social Justice Program, this program reaches out to 
prison inmates, who are all middle-class white men, and gets them involved in theatre. She notes that this is a demographic concern because more black men are incarcerated in Oregon than the national average, but black men do not tend to participate in the program. As McMaster notes in his piece, it could potentially come back to theatre's history of racism. On a larger level, Spencer recognizes that theatre in America has an "us versus them" mentality, meaning that audiences are often simply viewing the performance, rather than truly engaging. Some have broken through this barrier, but it is rare and not majorly present in theatre and in Portland, in particular.

Spencer also brings up the example of Maya Angelou and her experience in touring the play The Blacks. The show addresses the status of white people and their privilege. Apparently, the audiences would express to her that they understand her struggle. Spencer reiterates that white people do not have the ability to understand the experiences of people of color. This is why there needs to be applied theatre immersing these audiences who are not being addressed to the full extent. She says that Portland needs to do more of this. Our demographics as a whole lack diversity, therefore there must be an effort made to become inclusionary. Although necessary discussions to make this happen may be uncomfortable, nothing will change if the cycle perpetuates. I think Spencer's voice is critical, as I believe many would look at such a program and only see the good in it. However, the challenges that theatre faces find their way into these programs as well and they must continue to be fought.

\section{Descriptive Audio Services in Portland, OR}

Valory Lawrence, who is a professor at Portland State University, among wearing many other hats, spoke with me about her work doing audio description for the visually impaired (V. Lawrence, personal communication, April 10, 2017). Audio description assists the visually 
impaired in following along with a theatrical performance. These services are primarily used by theatregoers that are Blind. Someone, like Lawrence, describes the play live and the theatregoer uses the service listens via headset. She mentions that quite a few theatre companies in Portland use it, including Portland Center Stage. These services are not as widely used as ASL interpretation, as it is challenging to find space for equipment, even though ASL interpretation is a challenge in that regard as well. They are in desperate need of new equipment, as they are using the same equipment they have had since they started these services 22 years ago. It is a lot of hard work to offer these services, with very little support.

Lawrence believes that accessibility is decent in Portland, especially compared to Seattle, as descriptive audio services is not offered in their theatres. Accessibility may not necessarily be a diversity factor, however if disability services are offered, then more audiences will feel comfortable attending a theatrical performance. Lawrence mentions Northwest Children's Theater and their sensory-friendly shows for children with autism. Many theatre companies utilize hearing enhancement services and open captioning services, which are often cheaper options. The reality is that many theatre companies are cutting many of these resources for their audiences when more of these services should be offered. It is now seen as much easier to focus our phones, so true effort must be made to welcome audiences from every background. As a caveat, Lawrence offers that representing the audience base is a way that this can be improved. She even is in the process of working with the School for the Blind and working with the children there, so they can create theatre through touch and sound. 


\section{Strategies \& Suggestions to Aid in the Success of PNW Theatre}

Based on the strategies used by theatre companies nationally and with the PNW perspectives, I will now pose five strategies and suggestions that could aid in the success of PNW theatre's efforts to be diverse and inclusive. The list of strategies and suggestions is limitless, but as Marcella Crowson at Oregon Children's Theatre reminds, theatre companies must start somewhere. Small strides can come together to make a larger impact, as will become clear with strategy \#5. The items on this list may be easier said than done, but with monitoring of progress, I'm confident change could occur.

\section{1) Be mindful that your theatre company can do more than entertain audiences}

Bhattacharya and Gupta made this important strategy clear throughout my analysis and PNW theatre companies should be mindful of it and refer to it often. Of course, the entertainment side is what can create revenue for a company, so there is a fine balance. Many PNW theatre companies could do more to inform, instruct, persuade, educate, and develop. I think that the PNW theatre companies that provided me with comments have a lot going for them, but they also are aware of their shortcomings. It does make me wonder if those that did not respond to my requests do not have those similar initiatives and did not feel as though they could comment. Either way, whether a theatre company has the main aim to entertain or not, knowing that the reach can extend past that is the first step. Theatre has the power to influence people in transportive ways and that should not be taken lightly.

\section{2) Make bold casting decisions and keep in mind who are in your audiences}

Many PNW theatre companies note that they are casting people of color, Imago for instance, so this strategy is floating about freely, as it should. With Broadway Rose, they say that 
they do not have diverse people auditioning for their shows. I do not know the validity of this, but I do understand that Tigard is a predominantly white area. There are many in the Hispanic community there, however, so it becomes a little tricky. That being said, a theatre company must keep in mind who is in their audiences, but also who should be in their audiences. Why aren't there more Hispanic theatregoers visiting their theatre? Regardless, I am pleased to say that I haven't been made aware of any casting fiascos like there was at Lincolnshire's Marriott Theatre with their casting of Evita. I'm hopeful PNW theatre companies can continue to cast authentically. There is also the factor of presenting theatre that is relevant to the community in which it is being presented. This will likely work differently depending on the theatre company, but theatre companies such as Teatro Milagro, which highlights Latinx shows, do already help carve out a space for people in the PNW.

\section{3) Welcome young people into your theatre and create the next generation of theatregoers}

Attendance from children at theatrical performance is apparently up by $14 \%$, but this is a challenge for me to believe in a PNW context. 1.9\% of survey respondents at Artists Repertory Theatre were under 18 . I attend many productions around the city and I can say that this sounds fairly representative. However, Oregon Children's Theatre and Northwest Children's Theater, as well as children's theatre in Seattle and across the PNW, may make up for that difference. These child-specific theatre companies give them their space to shine, but many "adult" theatre companies are adding children into their missions to make them feel included at the dozens of other theatre companies in the PNW. This is the next generation of theatregoers. It is much easier for them to focus on things such as social media, so they need to grow up loving theatre so that the art can continue to thrive. Portland Center Stage is particularly innovative in how they reach 
young people, through programs such as their teen council. Their Visions \& Voices playwriting program for high schoolers harbors the fact that not only are these future theatregoers, but they are the people who are going to be creating the theatre of the future.

There is also the caveat of casting children in productions as well. Specific children's theatre companies obviously cast children often, however incorporating children into the rigorous and more standard theatre company poses challenges. If one is to look at the most recent 2017 Actors' Equity Association's rulebook for the League of Resident Theatres, they would see lists of rules pertaining specifically to children. There is a lot more to consider when a child takes on a role in an equity show. All of this may be considered by theatre companies to include children, though it is likely to be much more tricky. It is powerful for a child to see another child on stage. It shows them that they can get up on the stage as well.

\section{4) Provide necessary services to those who need assistance experiencing theatre}

For most theatregoers, accessibility is not a major concern of theirs, so it might be hard to determine how great of a need there is for disability services. However, whether that is because there isn't a need for them or whether these groups aren't attending theatre because they don't feel the services they need are offered, remains to be clear. Valory Lawrence expressed, for example, that there is actually a sizeable portion of the Portland Deaf community that goes to see theatre, so I find it challenging to believe that the need is not there. ASL interpretations is the most developed of the services offered, so it would make sense why there is a larger fanbase. Services such as audio descriptions and sensory-friendly environments are not as widespread. If theatre companies tout themselves as safe spaces, I think it makes sense to provide as many 
services as possible and to extend past the "special event night" where they can be included and experience theatre as it is intended.

Funding is a large factor here, as I know theatre companies would love to have as many services as possible, I am sure. Oregon and Washington have very little funding for the arts, so there is clearly this obstacle to climb. Perhaps finding creative ways to fundraise for accessibility services is something to consider. Lawrence has this idea to have a fundraiser where audience members experience the first act of a show with very low lighting and audio description, so they can experience what it is like for someone with visual impairment. The second act would be ASL interpreted, with dialogue as well as most would likely not understand the story without it, to experience what a Deaf audience member would experience. This is one of many innovative ideas to assist people in understanding the importance of accessibility. Assisting audience members with disabilities to whatever extent possible is the aim here and they should not simply be an obligation - they should be celebrated.

\section{5) Foster the mission of diversity and inclusion until it has been integrated systematically}

This strategy is the most important one to keep in mind. These small diversity and inclusion initiatives are important, but they are not the end-all-be-all. For example, if a company is casting diversely, this does not mean that the staff is diverse or the pieces they choose to produce are diverse. These changes must become systematic, or else they are simply side projects that fall flat. Throughout the paper, I have mentioned numerous strategies that have been successful. These strategies have done a lot of good, but they must work together with other strategies. As Luis Alfaro suggests, a theatre company must get everyone on board. Similar to how people say it takes a village to raise a child, it takes a theatre company to create a successful 
production. From the box office to the cast itself, education and passion must happen on all levels for change to occur. Theatre companies also must come together and share these goals, to create a unity so that the PNW can set the example for other theatre companies nationally.

\section{Conclusion and Limitations}

I hope that both regular theatregoers and those who are not see the value of diversity and inclusion initiatives within theatre companies. This paper's goal was to explore the state of PNW theatre and how successful theatre companies in this region are at promoting diversity and inclusion. This was done by an extensive literature review and analysis that included sections on the current state of theatre in America and its importance, an introduction to the people, pieces, and companies setting the example for diverse and inclusive theatre practices, the national theatre versus regional theatre debate, and successful integrative strategies used by companies and by specific individuals. There was then a report on interviews that have been conducted with local PNW theatre companies. Finally, after looking to strategies used across the country and examining it in relation to PNW voices, I proposed suggestions as to how the PNW can grow with presenting and fostering theatre that is diverse and inclusive.

One of the limitations I had with my research is that there truly is an expansive amount of literature that could be included in a literature review. Daily, I receive alerts from American Theatre Magazine and I wanted to include many of their pieces in this paper, but I recognize that the research must end somewhere. I feasibly could continue to be an advocate for diversity and inclusion within the theatre community, as I know the topic is always evolving. Another limitation with my research is that there were very few theatre companies that responded to my request to get their opinion on the subject. I am extremely grateful for those who took the time to 
contribute, but it would have been useful to have additional perspectives, as there are many theatre companies in the PNW. I especially understand that I need more information on Seattle and other PNW cities and states. As I stated earlier, the attempt was made.

I am certainly not so naive to think diversity and inclusion is an easy course to navigate, but if we don't keep discussing the tough issues, there will be very little progress. Recently, Artists Repertory Theatre hosted a touring production of Rodney King and a post-show discussion spiraled out of control. An audience member expressed their racist opinions, which resulted in audience members feeling unsafe and unwelcome. Even with the best efforts made to make theatres safe spaces, there is a lot to accomplish still. It is also challenging to bring in audiences to see new work because we are so accustomed to the "classics." This doesn't change the fact that theatre is evolving, just as the world we live in is, and that is what makes it a beautiful and challenging art. Without preserving theatre in its most authentic form, theatre in our society may fail to survive. Through promoting diversity and inclusion and making theatre accessible to as many as possible, the art will extend to more people than ever before and be an accurate representation of our world. 


\section{References}

Am I Right? (n.d.). Tumblr. Retrieved from http://projectamiright.tumblr.com

Artists Repertory Theatre. (2017). Audience survey data collection [Data file]. Portland: Artists Repertory Theatre.

Aucoin, D. (2012, June 30). Rethinking theater, and ways to make it, in the digital age. The Boston Globe. Retrieved from https://www.bostonglobe.com/arts/theater-art/2012/06/30/the-challenge-how-make-theate r-relevant-digital-age/I8Ngc0Ewea8jG4wzkpkCJO/story.html

Bhattacharya, K.K., \& Gupta, D.D. (2013). Interpreting theatre as a communication medium. Global Media Journal-Indian Edition, 4(2), 1-10. Retrieved from http://www.caluniv.ac.in/global-mdia-journal/ARTICLE-DEC2013/Article_13_Kapil_K umar_Bhattacharya_\&_D_D_Gupta.pdf

Bowles, N., \& Nadon, D. (Eds.). (2013). Theater in the Americas: Staging social justice: Collaborating to create activist theatre. Carbondale and Edwardsville, IL: Southern Illinois University Press.

Clement, O. (2017, February 09). Last year's Evita casting controversy inspires Project Am I Right. Playbill. Retrieved from http://www.playbill.com/article/last-years-evita-casting-controversy-inspires-project-am-i -right

Clement, O. (2017, February 17). For military veterans, theatre saves lives. Playbill. Retrieved from http://www.playbill.com/article/for-military-veterans-theatre-saves-lives 
Culture Clash. (2003). Culture Clash in AmeriCCa. New York, NY: Theatre Communications Group, Inc.

Demby, G. (2016, March 08). Watching a brown 'Hamilton' with a white audience. Code Switch: National Public Radio. Retrieved from http://www.npr.org/sections/codeswitch/2016/03/08/469539715/a-brown-hamilton-a-whit e-audience

The demographics of the broadway audience: 2014-2015 season. (n.d.). The Broadway League. Retrieved from https://www.broadwayleague.com/research/research-reports/ de Place, E. (2010, October 27). The Northwest's racial diversity. Sightline Institute. Retrieved from http://www.sightline.org/2010/10/27/the-northwests-racial-diversity/

Eyring, T. (2016, March 22). What's so special about kids today? American Theatre. Retrieved from https://www.americantheatre.org/2016/03/22/whats-so-special-about-kids-today/

Garrison, M.R. (2017, March 21). Exploring race relations in Portland through arts. HubPages. Retrieved from https://hubpages.com/entertainment/Exploring-Race-Relations-in-Portland-Through-theArts

Ghostlight Project. (n.d.). The Ghostlight Project. Retrieved from https://theghostlightproject.com/action-statement/

Grunfeld, A. (2015, December 21). Why America needs a national theatre - But it might look different than you think. Playbill. Retrieved from http://www.playbill.com/article/why-america-needs-a-national-theatre-u2014-but-it-migh t-look-different-than-you-think-com-376231 
Journey, E. (2015). Frank Wedekind's Spring Awakening and the tragedy of adolescence.

Theatre Symposium 23, 20-29. Retrieved from

https://muse-jhu-edu.proxy.lib.pdx.edu/issue/32533

Livestreaming the 31st annual Literary Managers and Dramaturgs of the Americas

Conference-Portland, OR—Thurs, July 7-Sat, July 9—\#LMDA16. (2016, July 9).

HowlRound. Retrieved from

http://howlround.com/livestreaming-the-31st-annual-literary-managers-and-dramaturgs-o f-the-americas-conference-portland

McMaster, J. (2016, February 23). Why Hamilton is not the revolution you think it is.

HowlRound. Retrieved from

http://howlround.com/why-hamilton-is-not-the-revolution-you-think-it-is

O’Quinn, J. (2015, June 16). Going national: How America regional theatre movement changed the game. American Theatre. Retrieved from

http://www.americantheatre.org/2015/06/16/going-national-how-americas-regional-theatr e-movement-changed-the-game/

Perez, K., \& Corey, F.C. (2015). Access and accessibility: Performance encounters. Text and Performance Quarterly, 35(2-3), 91-94. doi: 10.1080/10462937.2015.1037547

Rose, H. (2011). A conversation with Anna Deavere Smith. Text and Performance Quarterly, 31(4), 440-448. doi: 10.1080/10462937.2011.604969

Shaw, H. (2016, September 21). The state of the play: A critic addresses the theatre nation. American Theatre. Retrieved from 
http://www.americantheatre.org/2016/09/21/the-state-of-the-play-a-critic-addresses-the-t heatre-nation/

TED. (2007, March 23). Anna Deavere Smith: Four American characters. Retrieved from https:/www.youtube.com/watch?v=KR8SwPmCFd4

Tran, D. (2016, October 18). 'After Orlando,' Playwrights step into the breach. American Theatre. Retrieved from http://www.americantheatre.org/2016/10/18/after-orlando-playwrights-step-into-the-brea ch/

Zoukis, C. (2017, March 29). Prison Shakespeare programs have dramatic impact on inmates. The Huffington Post. Retrieved from http://www.huffingtonpost.com/entry/prison-shakespeare-programs-have-dramatic-impac t-on_us_58dc09d7e4b04ba4a5e25019 


\section{Appendix A}

Survey Questions Administered to Harlequin Productions, Imago Theatre, and Portland Center

\section{Stage}

1) In general, how successful do you think the PNW is in presenting theatre that is diverse and aiming for inclusion?

2) What is the biggest obstacle you see PNW theatre having to face or is facing currently?

3) How successful do you think (specific theatre company) is at promoting diversity and inclusion? What strategies are used?

4) Would you say (specific theatre company) has the "traditional" theatre demographic? (By this I mean the older, white, well off audiences I see at the theatre company I intern at)

5) Does (specific theatre company) contribute to the community in a unique way? How so? 


\section{Appendix B}

\section{Survey Questions Administered to Oregon Children's Theatre}

1) In general, how successful do you think the PNW is in presenting theatre that is diverse and aiming for inclusion?

2) What is the biggest obstacle you see PNW theatre having to face or is facing currently?

3) How well do you think Oregon Children's Theatre is at promoting diversity and inclusion? What strategies are used?

4) How does Oregon Children's Theatre foster such a unique demographic within the theatre community?

5) Does Oregon Children's Theatre contribute to the community in a unique way, other than the demographic component? How so? 